\title{
増加交通配分法の実用化に関する研究 \\ STUDY ON THE PRACTICAL INCREMENTAL ASSIGNMENT METHOD
}

\author{
杉恵 頼 寧* \\ By Yoriyasu Sugie
}

\section{1. はじめに}

交通量り配分手法は大型電子什算機の導人によって飛 躍的な発展をとげ，これまで多くの手法が提案されてい る。その中でいくつかの交通量配分手法の実用性が認め 门れ，各地域り交通叶曲で定着しつ一るる。増加交通配 分法 (Incremental Assignment Method) はアメリカ の Martin 等によって提案された手法であり ${ }^{1) 21}$ ，まだ 奏際の交通叶画では用いられていないが，そのアイデテ が興味深く，その奏用化が望まれている。そこで，本論 文は増加交通配分法の実用化を試み, さらにこの配分法 の将来の発展性について検討しようとするものである。

\section{2. 増加交通配分法の説明}

従来の配分手法は分存モデルから得られたゾーン間交 通量を一定とし, 配分によって生じる道路網の混雑状態 を考鲞しないで, そのゾーン間交通量をすべて道路網に 配分している。すなわち, グラビティモデル等の分布モ デルにおいて, ゾーン間交通量はゾーン間の所要時間を 変数としているが, 道路網の各リンクの所要時間はリン クの交通量に基づいて定まるため, 実際には交通量配分 の前にン゙ーン間の所要時間を知ることはできない。そこ で, 各リンクひ所要時間を想定してゾーン間の所要時間 を叶算し, ゾーン間交通量を求めている。その結果, ゾ ーン閒交通量は分布そデルの性質上ゾーン間の所要時間 の関数として表わされるにもかかわらず固定されてしま う問題点を有する。

これに対して, 増加交通配分法は「発生率曲線(Generation Rate Curve)」を導入し, ゾーン間交通量を一定 としないで, 交通量配分後の道路網の混雑状態を考慮し て, ゾーン間の配分対象交通量を決めようとする手法で

$*$ 正会員 工博 広島大学助教授 工学部土木工学科
ある。この配分法には次の 5 種類のインプットデータが 必要になる。

(1) 人カゾーン間交通量 (Input Zonal Volume)--道路網の各リンクの交通量が 0 のときのゾーン間の所要 時間を用いてグラビティモデル等の分布モデルによって 算出しておいたゾーン間交通量である。

(2) 道路網表示一一ノード番号, リンク長, 各リンク の車線数，各リンクの規格。

(3) 容量制限式—リンクの所要時間と交通量の間の 関係式。

(4) 増分交通量 一プログラムの反復計算で配分され る交通量で, 入力ゾーン間交通量に対する割合（たとえ ば 10\%), あるいは一定数（たとえば 200 台）で示され る。この増分交通量は少ない方が望ましいが, 計算時間 の関係から任意に定めればよい。

(5) 発生率曲線—ゾーンペア間の最短経路の単位所 要時間 (Unit Travel Time) を変数としてその需要量 を表わした曲線であり, 入力ゾーン間交通量に対する比 率で示される。需要量とは任意の単位所要時間 (分 $/ \mathrm{km}$ ) のとき, そのゾーン間の走行 (Travel) を希望する交通 量である。

発生率曲線はトリップの属性，たとえばトリップ目的 A，B，C などによって異なり，その一般的な形は図一1 のように表わされる。これらの曲線は道路網が混雑して くると(ゾーン間の単位所要時間が長くなる), ゾーン 間交通の需要量が減少してくることを意味している。こ れはグラビィティモデルから明らかである。この発生率 曲線が与えられたとすると(この曲線についてはあとで くわしく述べる), 増加交通配分法の計算手順は次のよ うになる。

まず配分すべきゾーンペアをランダムに選ぶ。次に， リンクの交通量が 0 のときの所要時間を用いてそのゾー ン間の最短経路 (Minimum Path) を決定し, その経路 の単位所要時間を計算する。さらに, 発生率曲線から人 


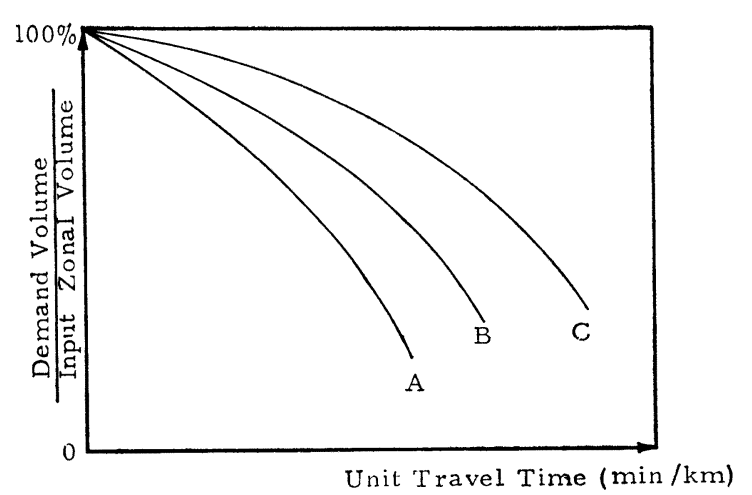

図一1 発 生率曲線

カゾーン間交通量に対する需要量の割合を求める。配分 をはじめるときその割合は $100 \%$ である。もし入力ン゙ ーン間交通量が 1000 トリップならば，1000 トリップ がそのゾーンペアの需要量になる。次に，それまでの配 分計算でそのゾーンペアに配分されたゾーン間交通量 (配分済交通量) とこの需要量とを比較する。最初の計 算では, 配分済交通量は 0 であり, 需要量の方が多いの で, 増分交通量をその最短経路に配分する。もし増分交 通量が $10 \%$ ならば，100 トリップを配分する。もし一 定数 200 トリップならば，200トリップが配分される。 增分交通量を最短経路に配分した後, 容量制限式を用い て交通量を配分した最短経路のリンクの所要時間を修止 する。

このようにして，ゾーンペアをランダムに選んで，そ のゾーンペアの配分を何回かくり返すと道路網は少しず つ混雑し, ある任意のゾーンペアの需要量が発生率曲線 より人カゾーン間交通量の $95 \%$ になったとする。この 例の場合は 950 トリップである。一方，それまでにその ゾーンペア間に配分されたトリップが 800 トリップであ ったとする。増分交通量が $10 \%$ ならば, 100 トリップ がそのゾーンペアの最短経路に配分される。増分交通量 が 200 トリップならば, 需要量と配分済交通量の差 150

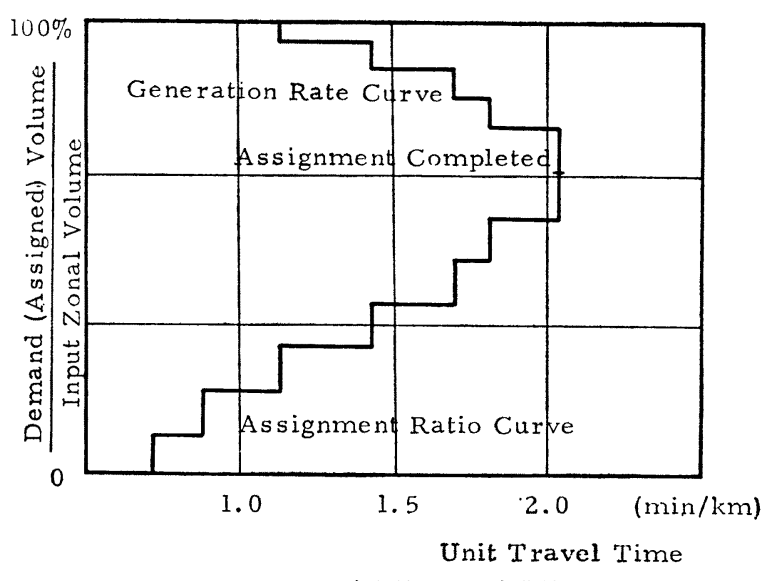

図- 2 発生率曲線と配分率曲線

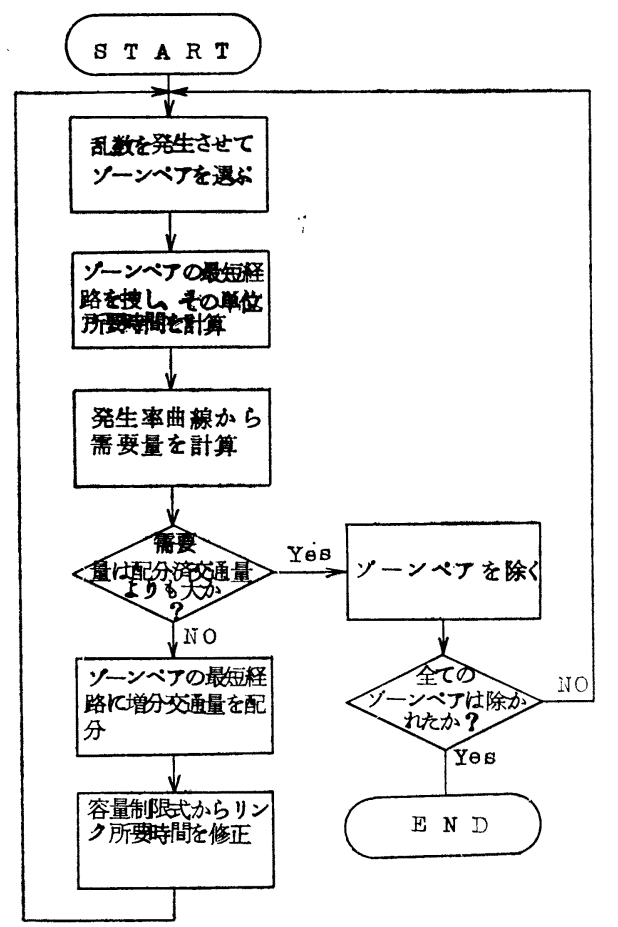

図一3 增加交通配分法の計算プロセス

トリップが配分される。こりようにして, 配分済交通量 が需要量に等しくなったらそのゾーンペア間の配分は先 了し, 今後の配分計算の対象からそのゾーンペアを除 く。これらの関係を表わしたのが図一2であり, ゾーン 間の配分済交通量とその単位所要時間の関係を示した曲 線を配分率曲線 (Assignment Ratio Curve) と呼ぶこ とにする。図一2 の両曲線とも配分プロセスの都合上階 段状に変化し, 両曲線の交点が求める均衡解である。

このようにして, すべてのゾーンペアで発生率曲線と 配分率曲線が一致すると配分は完了することになる。こ の計算プロセスをフローチャートにホ⿱す丶と図一3のよう になる。

増加交通配分法はこのように需要量を一定とみなさ ず, 道路網の混雑の度合 (単位所要時間) を变数とし て表わしており，非常に興味ある手法であるが，実際 にはこの発生辯曲線を知ることは非常にむずかしい。

\section{3. 增加交通配分法の実用化}

増加交通配分法のう:特色は「ゾーニ間の自動車卜 リップの需要量がその単位所要時閒の関数で表わされ る」ことにある。しかし, 一般に交通量配分の対象と なる自動車トリップは一定であるため, 現在のところ このアイデアは十分生かされているとはいい難く, 奏 用的な配分手法になっていない。そこで，ゾーン閒交 
通量が一走といら前提のもとにこの 特色を少し 発展さ せ，次のような配分手法を考えてみた。

\section{（1） 発生率曲線の応用}

増加交通配分法の発生率曲線を実験的に知ることは非 常にむずかしいが，次のような考え方でその曲線のアイ デアを応用することが川能である゙)。

現在実際の交通計画で用いられている配分手法は, 運 転者がすべて道路の混雑状態を示した道路網図を頭の中 に描き，常に最短経路を探索してその経路を取ることを 基本にしている場合が多い。しかし, 現実には運転者が 前もってす心゙ての経路の混雑状態の情報を知ることは不 川能で, まして刻々変化するリンクの所要時間を計算し て経路を選ぶことは非現実的である。運転者はある混雑 度に達するまでは出発時に考えた最短経路を取り，ある 一定の混雑度に達してはじめてその混雑度を認識し, 別 の経路を捜すと考えたおがより現実的である。これに発 生㳯曲線を哀用するこ上ができる、ある一定の混雑度と は図一2の発生率曲線と配分率曲線の交点における单位 所要時間とする。この単位所要時間に達するまでゾーン 間の配分の対象となる経路は一定である。

発生㳯曲線は常に一起であるとは限らない。むしろ道 路網全体の混雑度が大きくなると, 運転者の心理として 交通施設のサービスに対する期街を少しドげるようにな ると考えられる。すなわち,これは 1 日の時間帯等によ るネットワーク全体の交通事情の変化に応じて，たとえ 混雑度が问じであっても需要量が異なってくることを意 味している。

このことは発生摔曲線が図一4のように $c=1$ から $c$ =2に移行することに相当する。cは発生率曲線が変化 した回数を表わしており, 計算プロセスでは反復計算の 回数を意味している。図-4の $c=1$ は図一2 に相当 し, 発生率曲線が一定ならば，前節で説明したように $c=1$ で配分が完了することになるが，発生率曲線が $c=$ 2 になるとゾーン間の需要量が配分済交通量よりも多く なる。

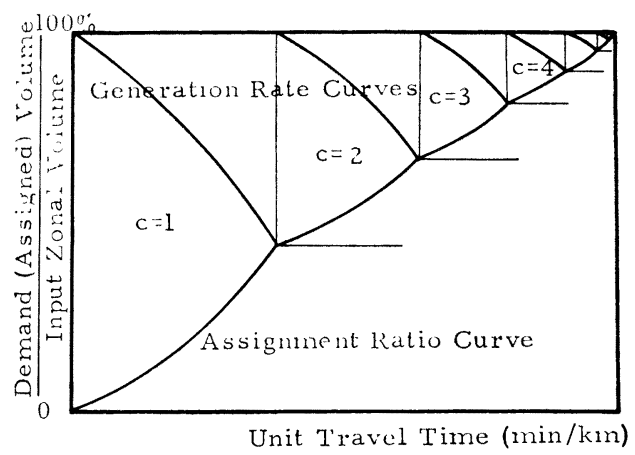

図一4発生率曲線を用いた增加交通配分法の反復計算
このようにして, 発生率曲線と配分率曲線が一致する たびにすべてのゾーンペアの最短経路を修正し, 発生率 曲線を移行させていくと与えられたゾーン間交通量をす ベて配分することが可能になる。配分プロセスは基本的 に増加交通配分法と同じであり, 次のようなステップを 踏む。

(1) すべてのゾーンペアの最短経路を決定する。

(2) 1 ゾーンペアをランダムに選ぶ。

(3)そのゾーンペアの最短経路の単位所要時間を計算 する。

(4) 発生率曲線からの需要量とそれまでの配分済交通 量を比較する。もし需要量の方が大きければ(5に進 み, 配分済交通量が需要量に等しいか, あるいはそ れよりも大であれば，配分の対象となるジーンペア を並ベたゾーンペア表からそのゾーンペアを除いて (2)にもどる。

(5)与えられたゾーン間交通量の一定割合（増分交通 量）を(1)で求めた最短経路に配分する。

(6) 道路網のリンクの所要時間を容量制限式から修正 して(2)に進む。

(1)一6の各ステップを続けていくとしだいに需要量と 配分済交通量が一致寸るゾーンペアが増え, ゾーンペア 表から配分の対象となるゾーンペアが減少していく。ゾ ーンペア表からすべてのゾーンペアが除去されると, 発 生率曲線を図-4の $c=2$ のよ5に修正し, 改めてすべ てのゾーンペアで $c=2$ の発生率曲線からの需要量と配 分済交通量を比較すると需要量の方が大きくなる。需要 量の方が大きいゾーンペアをゾーンペア表に並ベ，さら にそのときのリンクの所要時間を用いてすべてのゾーン ペアの最短経路を修正し, (1)一(6)のステップを続ける。 発生率曲線が再び修正されるまではすべてのゾーンペア の経路は一定である。このようにして, 発生率曲線を修 正しながらこのプロセスを続けると与えられたゾーン間 交通量がすべて配分されるゾーンペアがでてくる。この ゾーンペアは配分が完了したことになり,すべてのゾー ンペアで与えられたゾーン間交通量が配分されるとこの 配分プロセスは完了することになる。

このプロセスで用いる発生率曲線は運転者の実際の需 要量と必ずしも一致する必要はなく, 単位所要時間が増 えれば需要量が減少することを表わしていればよい。ま た発生率曲線の移行の割合も任意に定めればよく, 札幌 市の道路網への適用例では試行錯誤的に次のような直線 式を用いだ)。

$$
y=-1.0 x+1.90+0.30 c
$$

ただし $, y:$ 交通量が 0 のときのゾーン間交通量に対 する需要量の割合 $x:$ 単位所要時間 $($ 分 $/ \mathrm{km})$ 


\section{$c:$ 反復計算の回数}

この例では, 単位所要時間が 2.2 分 $/ \mathrm{km}$ のとき, 入 カゾーン間交通量に対する需要量の割合が $100 \%$ で, $x$ が大きくなるにつれてその需要量の割合は直線的に減少 する。 $y$ すなわち発生率曲線自体は反復計算ごとに $c$ が 1ずつ增え, 需要量の割合が $30 \%$ ずつ増加していく。

この配分法は確かに与えられたゾーン間交通量をすべ て配分する手法であるが，発生率曲線を修正するたびに ゾーンペアごとの道路網によるサービス水準, すなわち 道路網の交通量が 0 のときトリップを希望する交通量 (入力ゾーン間交通量) に対して，その走行を満足させ られた交通量（配分済交通量）の彗合を知ることができ る。この㓶合が小さいジーンペアほど混雑していて, 発 生摔曲線からの需要量が少ないことを意味している。こ れによって, どのゾーンペアが特に混雑しているか大体 の目安がつき, 道路網の收良の資料とすることも叮能で ある。

\section{（2）段階的增加交通配分法}

発生率曲線を用いた増加交通配法では「混雑度がある 一定に達するまで運転者はゾーン間の経路を変えない」 といら考え方に発生率曲線を灾用して抢り, 本来の発生 率曲線が持っている意味と少し異なってきている。そこ で,この考え方をもっと明確にするために, 発生率曲線 を用いないで次のような配分法を考えだ)。これを段階 的増加交通配分法と呼ぶことにする。

基本的には前記の配分法とほとんど同じであるが，発 生率曲線を用いないで, ある一定の混雑度というのを 1.5 分 $/ \mathrm{km}$ といらように具体的に表わし, その混雑度限 界に達するまで運転者はゾーン間の経路を変えないよう にする。その混雑度に達してはじめて別のゾーン間の経 路を捜し, さらに混雑度限界をたとえば 1.5 分 $/ \mathrm{km}$ から 2.0 分 $/ \mathrm{km}$ に修止し, この混雑度限界に達するまではそ の経路を変えない。

配分プロセスとしては最初にゾーンペアの最短経路を 捜し，すべて記憶しておく。次にゾーンペアをランダム に選んでゾーン間交通量の一定割合ず配分していき， あるゾーンベアが一定の混雑度限界（一定の単位所要時 間)に達すればそのゾーンペアを配分の対象から除く。 すべてのゾーンペアが除かれたのち（第 1 回目の反復計 算が完了), そのときのリンクの所要時間を用いて新し い最短経路を捜し, 混雑度限界を修正する。このプロ七 スを続けると，すべてのゾーン間交通量が配分される。 これをフローチャートに示すと図一5 のよらになる。

この配分法を札幌市の道路網に適用したとき, 混雑度 限界は試行錯誤的に $1.2 c, 1.0 c, 0.8 c$ (分 $/ \mathrm{km})$ の 3 式を用いた ${ }^{4)} 。 c$ は式（1）の上うに文復回数を示して扩

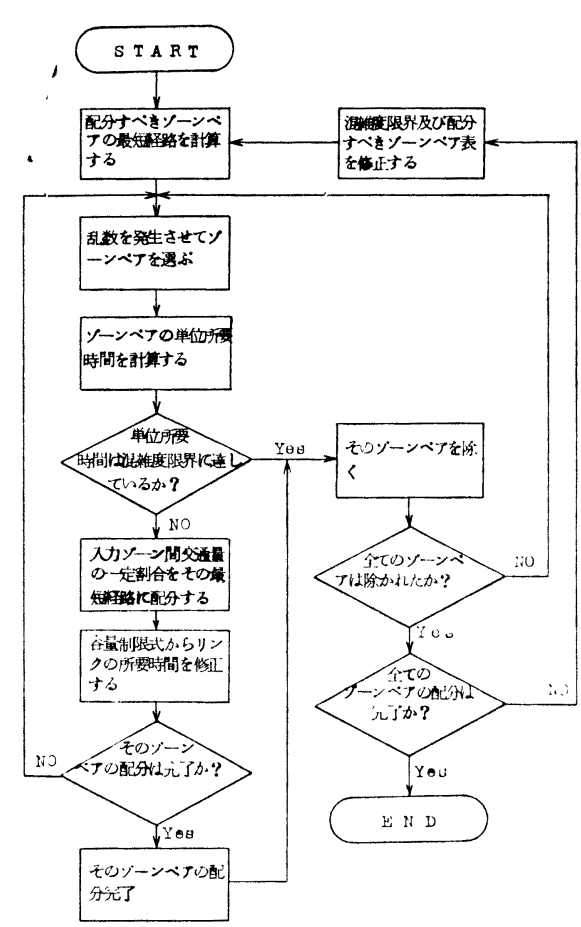

図-5 段階的增加交通配分法の計算プロセス

り, 最初の例では皮復回数がふえるごとに混雑度限界が 1.2 分 $/ \mathrm{km}$ ずつ増加していくことを意味している。

\section{4. 交通機関別分担を取入れた増加交通配分法}

前節では増加交通配分法の実用化を試みたが，この配 分法が本来持っている特色を十分生かしき，ていない。 しかもこの問題は単一の交通機関，たとえば目動車トリ ップのみを対象にしていたのでは不十分で，他の競合交 通手段の存在を考虑することが必要である。すなわち, 道路が混雑してくれば, 采用車の需要が減少し, 大量輸 送機関の需要がふえてくる。これは結局交通機関の間の 分担率を決める交通機関別分担 (Modal Split) の問題 に䚻着する。したがって, 増加交通配分法をこれ以上発 展させるには，交通機関別分担と配分交通を独立に扱う のではなく, 们らかの形で連動させる必要がある。

交通機関別分担を求めるには「利用济曲線 (Modal Split Curve)」を用いる手法がありこの曲線は発生㳯 曲線に類似している。そこで, 利用率曲線を䏘いて発生 率曲線のアイデアを生かし，さらに交通機閣別分担と配 分交通を関連づけるとができるかどうか検討してみる ことにする。

利用率曲線は, ゾーンベアの総パーソントリップが与. えられたとき, ゾーン間の交通機関別のサービス指標を 変数として, 各交通機関の分担率を決涑曲線である。 サービス指標としては, ゾーン間のコスト（時間十料 

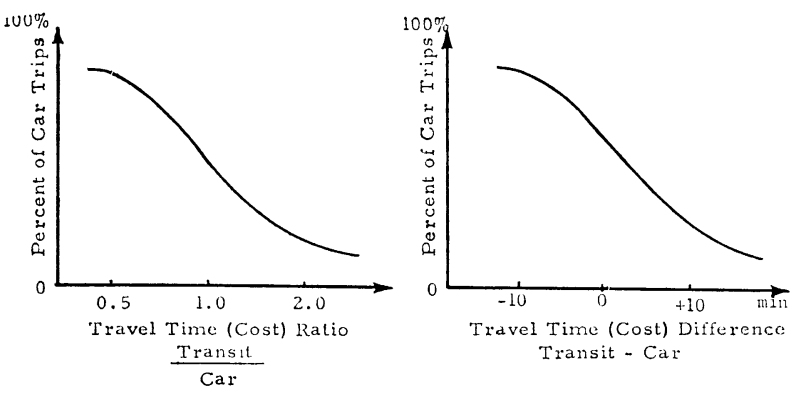

図一6 広岛都市圈の総合的交通計画で用いられた利用率曲線
金)，時間が一般に用いられ，機関別のコスト差，時間 差, コスト比, 時間比あるいはその組み合わせたものを 変数として機関別の分担率を表わすことが多い。一例と して，公島都市圈の総合的交通計画で検討されたコスト (時間) 比, コスト (時閒) 差を変数とした利用摔曲線 いパターンを示すと図一6 のようになる ${ }^{5)(6) 。 こ れ ら の ~}$ 曲線はトリッブひ目的别, 乘用車の有無别に作成されて いる。

今かりに，図一7 つようにゾーン i-j間に大星輸送機 関（鉄道十バス）と乗用車の㠹交通機関があって，种用 电の所要時間を $L_{i}{ }^{c}$, 大量輸送機関の所要時間を $L_{i}{ }^{m}$ 上し，怲交通機関の時間比 $R_{i}$ を次のように定義する。

$$
R_{i}=\frac{L_{i}{ }^{c}}{L_{i}{ }^{m}}
$$

道路が混雑すれば $L_{i}{ }^{c}$ が产くなるが，大量輸送機関の ルートに鉄道が含まれていると（大量輸送機関のルート がバスのみから構成されている場合は問題点としてあと で述べる)，鉄道の速度は交通量に関係なくほとんど一 定と考えてよいので， $L_{i}{ }^{m}$ は $L_{i}{ }^{c}$ ほど長くならない。 そこで， $R_{i}$ がしだいに大きくなり，図一6の時閒比を

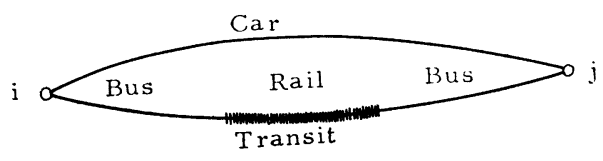

図一： i-j 間の競合交通手段

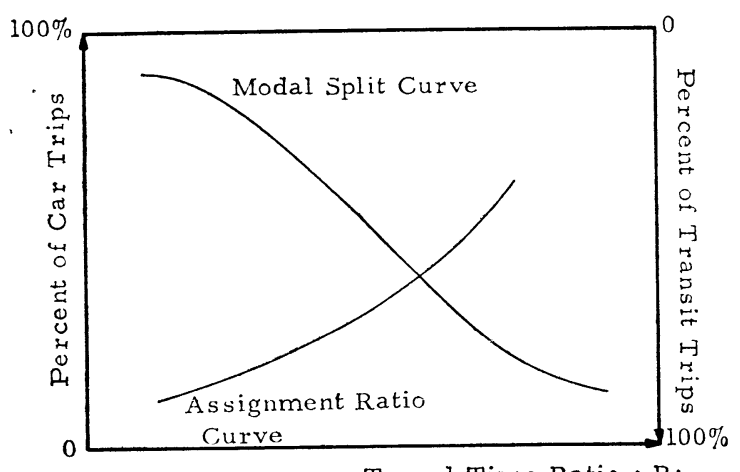

Travel Time Ratio : $\mathrm{R}_{\mathrm{i}}$

図一8 利用率曲線と配分率曲線
変数にした利用率曲線より, 乗用車の分担摔が減 少し, 逆に大量輸送機関の分担率がふえてくる。 この関係は先に説明した発生率曲線に相当し, 利 用率曲線は $R_{i}$ を変数としたときのゾーン間の総 パーソントリップに対する乗用車利用の需要量と 问時に大量輸送機関利用の需要量の割合を表わし ていることになる。この関係を示したのが図一8 の右下りの曲線である。

一方，道路網に乗用車のトリップを一定割合ず つ配分していくと, 道路網の各リンクの所要時間 と交通量の関係からゾーン間の所要時間が長くなり，利 用率曲線の場合と同じよらに $R_{i}$ がしだいに大きくなっ て，図一8の在上りの曲線を描くことができる。この曲 線は図一2 の配分率曲線に相当し， $R_{i}$ を変数としたと きのゾーン間の総パーソントリップに対する乗用車の配 分済交通星の㓶合を表わしていることになる。

図一8の関係は横軸の変数を $R_{i}$ に收っただけで図一 2 の関係と全く问じであり，屾曲線の交点で乘朋車の装 要星上配分済交通星が一致し, 利用率曲線の性質上: 采用 車の分担率の残りが大荲輸送機関の分担摔になるりで, 乗用車と大量輸送機関の分担率を同時に氷めることがで きる。

図一6のよ5に時間比以外に時㨨差，コス卜差，二久 ト比を変数に取っても図一8 と同じような関係が戊立す る。すなわち, 図一8の横軸の変数を時間差に取った埸 合, 委用車の交通量がふえれば凮交通機関の時間差は大 きくなり，図一8の右上りの曲線を描くことができる。 料金と所要時間を合戊したコストを変数に取ると，交通 量がふえても料金はほとんど一定であると考えてもよい ので，時閌を変数に取った場合と同じことがいえる。

このように, 利用率曲線を発生率曲線の一種と考える と, 乗用車のトリップは一定でなく, その所要時間を変 数として表わされ，第 2 節で紹介した増加交通配分法の アイデアを一歩前進させたことになる。

このモデルとしては増加交通配分法を発展させた段階 的増加交通配分法を一部修止して用いることができる。 すなわち, 乗用車の需要量を一走としていたのを利用率 曲線からその需要荲支求め, 次のような考え方に基一うい た大量輸送機関の配分プロセスをこのプログラムにつけ 加えればよい。

図一8 から明らかなよ5に，配分率曲線に沿一て乗用 电の配分が進んで行けば $R_{i}$ が大きくなり, 利用率曲線 より乗用車の分担率は少なくなっていくが，大量輸送機 関の方は利用率曲線に沿ってしだいにその分担率が増え ていく。したがって, 大量輸送機関の方は利用率曲線に 沿って増加した分担量を乗用車の配分と同時に大舅輸送 機関網に配分して行けばよい。その結果, 乗用車の分担 
率が均衡点に達した時点で, 大量輸送機関の配分も完了

していることになる。

計算手法としては, 図一3 のフローチャートのステッ プ1で混雑度限界を修正して, 道路の新しい最短経路を 探索する前にその時の大量輸送機関の需要量を大量輸送 機関のネットワークに配分し，大量輸送機関のバス台数 と道路網の乗用車台数を合成すればよい。なお大量輸送 機関のゾーン間の経路は一定とし，その経路にゾーン間 の大量輸送機関の需要量をすべて配分する需要配分を行 なう。

このような考えに基づいたモデルを INCREM (INCREMental Method) と呼び，その配分プロセスの前 提を整理すると次のようになる。

(1) ゾーン間の目的別パーソントリップ $\mathrm{OD}$ 表 (PTOD 表) 屿一定である。

(2) 機関別分担は乗用車と大量輸送機関 り間で行な 5 .

(3) すべてのゾーンペソで必ず秉用車上大量輸送機関 の涔交通手段が利用できる。

(4) 大量輸送機関は鉄道，バス，扩よび活交通機関の 間の乗換（徒步）リンクから構成さ机ている。

(5) 乘用电の代替ルートは複数本あるが，大量輸送機 関の経路は 1 本である。

(6) 鉄道と徒少の速度は一定である。

(7) バスの速度は问リンクの乗用車の速度の関数であ る。

(8) 道路網の各リンクの乗打車の速度はリンクの交通 量の関数である。

(9) 利用摔曲線はトリップ目的別に作成される。

(10) 利用率曲線は而交通機関のゾーン間の所要時間,

あるいはコスト（料金と所要時間を合成したもの）

の関数で表わされる。

これらの前提は取扱う対象範再を特別に狭くしたとい うわけではなく，既存の需要推計で用いられている前提 をまとめただけである7゙。この前提に基ぐき，時開比を 変数とした利用率曲線を用いると, INCREM の的算ブ ロ七スは図一9のようになる。この部算プロ七スでは利 用摔曲線と PTOD 㭊が目的别に少えられるので，目的 別に需要量を外算し，それを全目的の需要量に合部して それまでの配分済交通量と比較する。増分交通量は上え られた全目的 PTOD 表の一定㓶合とする。

この INCREM のシミュレーションが終った㭙点で， すべてのゾーンペアで機関別の需要量と配分済交通量の 均衡解が得られることになるが，次のような問題点を有 する。

(1) 貨物車のトリッブが無視されている。

(2) このシミュレーションでは，需要㫣と配分済交通

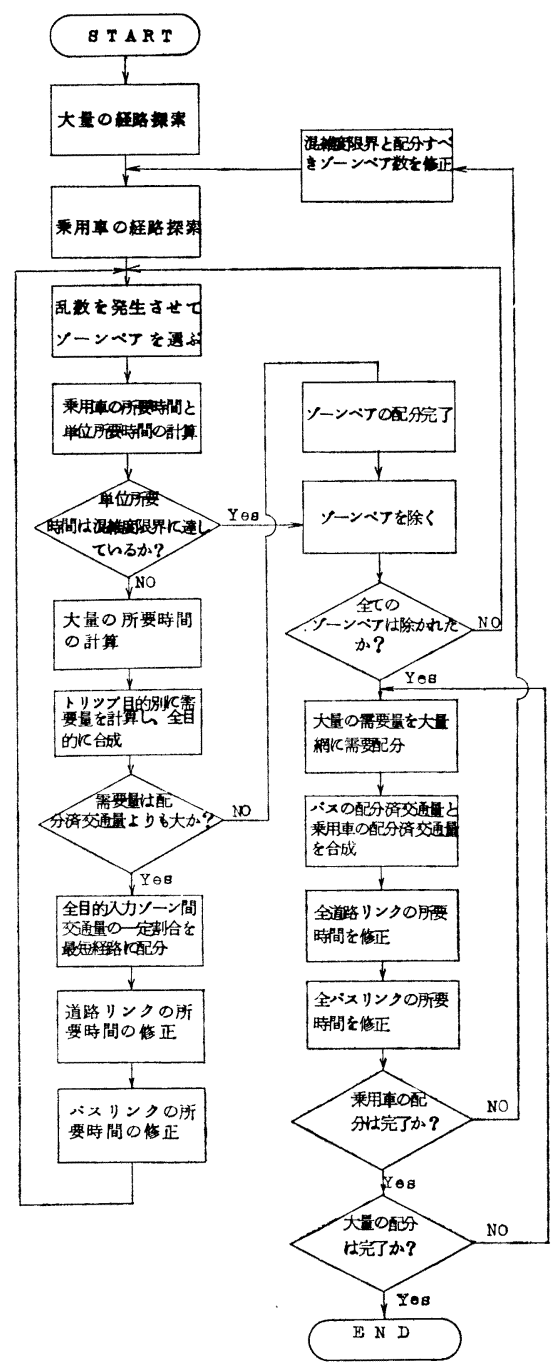

図一9INCREM の計算プロセス

荲が一致するゾーンペアから配分が完了して，配分 プロセスから除かれることになるが，他のゾーンペ アの配分が進むにしたがって，配分の完了したゾー ンペアの所要時閒が垃くなり，すべてのゾーンペア の配分が完丁した時点では, 初期の段階で配分の完 アしたゾーンペアり均衛がくずれている恐れがあ る。

(1)の問題に対しては，貨物电ひ掣要は道路ひ混雑度に あまり影響を受けないでほとんど一走であり，機関別分 担は行なわ和ないので，采用电の䣥分り前に貨物車の通 る幹線ネットワークを指示して，あらかじめ配分してお けばよい。そのあと, リンクの所要時間を修州して乗用 車の配分を行なえば，この問題は解決することになる。

(2)の問題は非常に本質的である。すべてのゾーンペア で同時に配分が完了しない以上，均衡点がシフトするこ とはやむを得ないので，姑算手法の一つの技法として， 
図一9 のフローチャートの 8 番目のステップ「需要量は 配分済交通量よりも大か?」で需要量と配分済交通量と を比較する場合，安全側をとって配分済交通量の方はそ のときの増分交通量を含めることにした。この比較にお いて, 配分済交通量の方が需要量よりも多いとそのゾー ンペアの配分は完了するわけであるが, その段階の増分 交通量を含めているから, 実際には配分済交通量の方が 増分交通量以内の差で需要量よりも少なくなっている。 これによって, ゾーンペアの配分の完了後, 均衡点があ る程度ずれても結果的には問題は少なくなると考えられ る。

しかし，均衡点のシフトの仕方がまちまちであるため， 先全にこの間題が解決するかどらか疑問であるので, 従 来り機関别分担と配分交通に分けて需要予測を行なら方 法上比較し，INCREM の有效性と同時にこの問題点を 検討してみる。この従来の手法に基でいた計算プログラ ムを TRADIT (TRADITional Method) と呼ぶこと に古ま。

\section{5. 従来の予測プロセス}

TRADIT は機関別分担乞配分交通が分離しているた め, 図一10 のように前者の ツリトプットが後者のイン プットになり，機関别分担の推計のとき用いたゾーン間 のサービス指標 $L_{1}$, たとえば所要時間等が配分交通の あとひゾーン間のサービス指標 $L_{2}$ と等しくなるか, あ るいはその差が一定の許容差 バックが何回か必要になる。

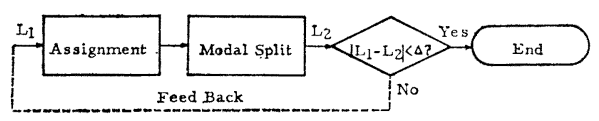

図-10 従来の予測プロセス

TRADIT \& INCREM と全く闰じ前提条件を必要と 玄る。はじめに大量輸送機関と道路網の各リンクに任意

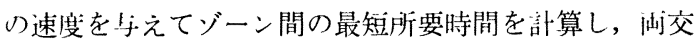
通機関の听要時閒の比か门利用率曲線を用いて, ゾーン ペソごとに沛交通機関の分担率を计算する。その機関別 OD 表を用いて各交通機関別に交通量を配分する。その 上きり各交通機関の需要量は一这である。道路網の配分

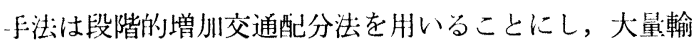
送機関の方は需要配分を行なら。その配分結果から乗用 車とバス台数を合成し，リンクの所要時間を修止して再 び機関別分担を行ない，配分をくり返す。機関別分担の 推計のとき用いたゾーン間のサービス指標と配分後のゾ ーン間のサービス指標との差がある一定の許容差に入れ ば,シミュレーションは完〕することになる。

\section{6. モデルの適用例}

ここでは INCREM の有効性を検討するために, 仮 想都市を想定してシミュレーションを行ない,TRADIT の結果と比較してみる。

\section{（1）仮想都市}

仮想都市は人山 234700 人の都心集中型を取り上げる ことにした。市街地は $14 \times 14 \mathrm{~km}$ の矩形型で図一11の ように 13 ゾーンのゾーニングが行なわれている。亘間 人口，夜間人口は同図に示したとおりである。トリップ の目的を $\mathrm{A}$ と $\mathrm{B} 22$ 種類に分け, 目的 $\mathrm{A}$ の発生トリップ は孯間人日, 目的 $\mathrm{B}$ の発生トリップは夜閒人日に依仔 し, トリップ目的別にパーソントリップ OD表が存在す る(表一1)。そのゾーン間の総パーソントリップは, 430410 トリップである。

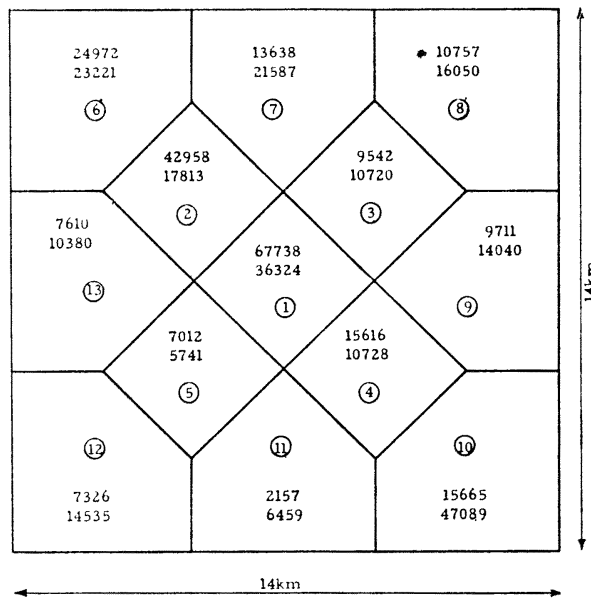

Upper Figure: Population in the Daytime Lower Figure: Population at Night (1) - (13) Zone Centroide

図-11 仮想都市のゾーニングと人口

交通機関は大荲輸送機関と乗用車の 2 種とし, 大量輸 送機関は鉄道とバスから構戊されている。井交通機関の ネットワークを四に亦すと図一12 のよ5になる（表一 2)。鉄道は放射状に配置されており，道路はグリッドバ ターンである。道路はすべて 4 車線の平直交差で 1 日 30000 台の谷最を有する。,゙゙ーン間の大量輸送機関の経 路を定める場合，バ久は道路網のすべてい区間を起るこ とができる。

交通機関の利用率曲線はトリップ甘的別に図一13 の ような值線式で表わされるとする。

大量輸送機関を利用する場合の経路は一定であり, そ の経路探索のときの鉄道の速度は $30 \mathrm{~km} /$ 時, バスの速 度は $15 \mathrm{~km} /$ 時, 徒歩の速度は $6 \mathrm{~km} /$ 時とする。ゾーン 


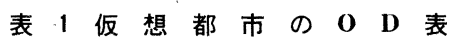

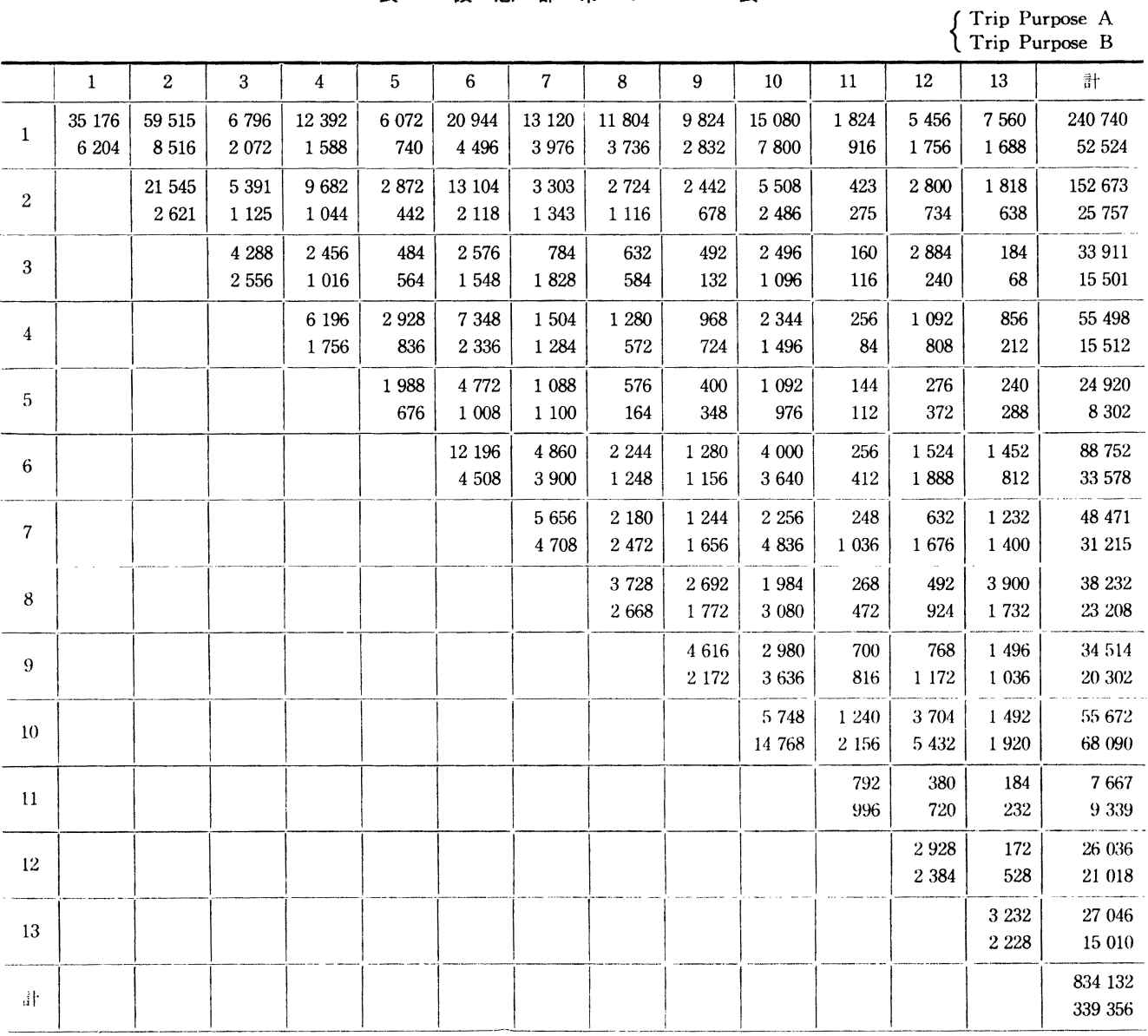

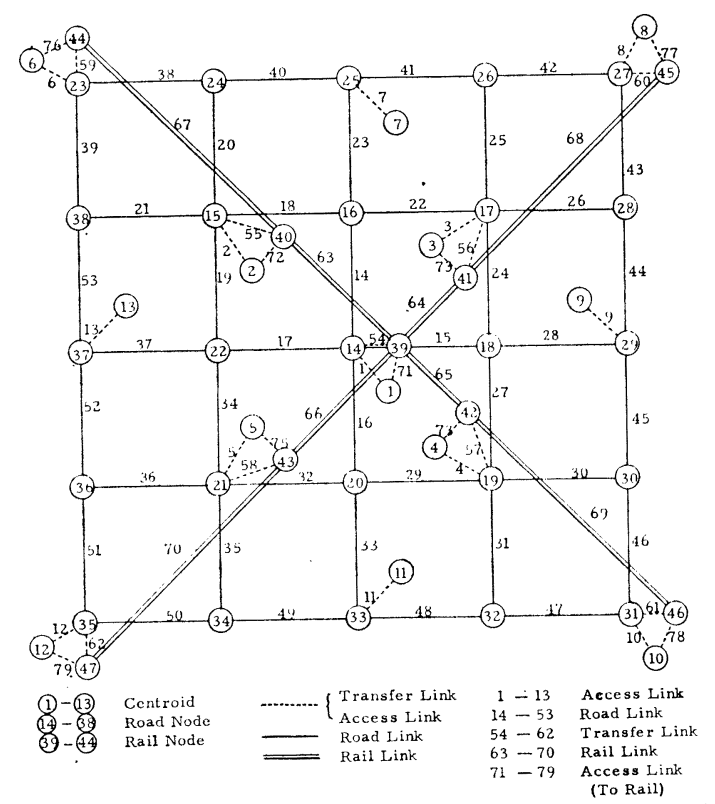

図一12 仮想都市の交通網

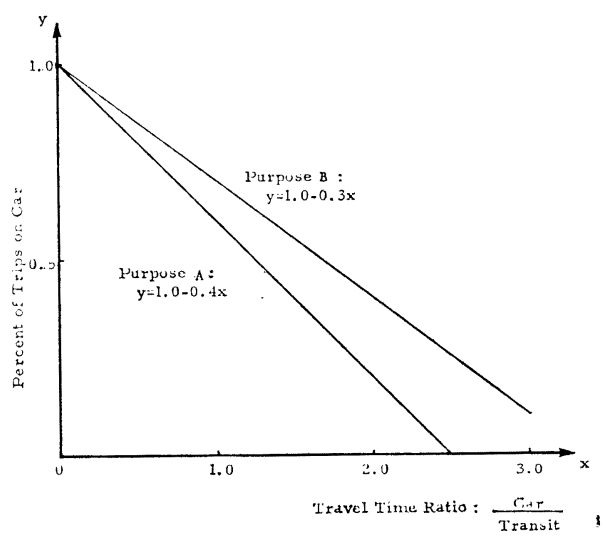

図-13 利用率曲線

間の所要時間を胡算する場合の鉄道と徒步の速度は一定 で上記の值を用いることにし，各リンクのバスの速度は 乗用車の速度の 0.7 倍とする。

乗用車の交通量が 0 のときの速度を $40 \mathrm{~km} /$ 時とし, 容量制限式は次のような関数を用いる。

$$
T=T_{0} \cdot e^{R}
$$


表一リンクテーブル

\begin{tabular}{c|c|c|c|c|c|c|c|c}
\hline Link & A-Node & B Node & Distance & Link & No. Node & B-Node & Distance \\
\hline No. & A & A & km \\
\hline 1 & 1 & 14 & 0 & 41 & 25 & 26 & 1.96 \\
2 & 2 & 15 & 0 & 42 & 26 & 27 & 3.08 \\
3 & 3 & 17 & 0 & 43 & 27 & 28 & 2.94 \\
4 & 4 & 19 & 0 & 44 & 28 & 29 & 2.26 \\
5 & 5 & 21 & 0 & 45 & 29 & 30 & 2.02 \\
6 & 6 & 23 & 0 & 46 & 30 & 31 & 2.74 \\
7 & 7 & 25 & 0 & 47 & 31 & 32 & 2.48 \\
8 & 8 & 27 & 0 & 48 & 32 & 33 & 1.82 \\
9 & 9 & 29 & 0 & 49 & 33 & 34 & 2.08 \\
10 & 10 & 31 & 0 & 50 & 34 & 35 & 2.70 \\
11 & 11 & 33 & 0 & 51 & 35 & 36 & 2.52 \\
12 & 12 & 35 & 0 & 52 & 36 & 37 & 2.38 \\
13 & 13 & 37 & 0 & 53 & 37 & 38 & 2.14 \\
14 & 14 & 16 & 1.36 & 54 & 14 & 39 & 0.10 \\
15 & 14 & 18 & 1.76 & 55 & 15 & 40 & 0.10 \\
16 & 14 & 20 & 1.44 & 56 & 17 & 41 & 0.10 \\
17 & 14 & 22 & 1.94 & 57 & 19 & 42 & 0.10 \\
18 & 15 & 16 & 2.00 & 58 & 21 & 43 & 0.10 \\
19 & 15 & 22 & 1.26 & 59 & 23 & 44 & 0.10 \\
20 & 15 & 24 & 2.78 & 60 & 27 & 45 & 0.10 \\
21 & 15 & 38 & 3.12 & 61 & 31 & 46 & 0.10 \\
22 & 16 & 17 & 1.74 & 62 & 35 & 47 & 0.10 \\
23 & 16 & 25 & 2.28 & 63 & 39 & 40 & 2.54 \\
24 & 17 & 18 & 1.78 & 64 & 39 & 41 & 2.74 \\
25 & 17 & 26 & 2.58 & 65 & 39 & 42 & 2.90 \\
26 & 17 & 28 & 3.22 & 66 & 39 & 43 & 2.66 \\
27 & 18 & 19 & 1.88 & 67 & 40 & 44 & 4.30 \\
28 & 18 & 29 & 2.14 & 68 & 41 & 45 & 4.46 \\
29 & 19 & 20 & 1.48 & 69 & 42 & 46 & 4.08 \\
30 & 19 & 30 & 2.26 & 70 & 43 & 47 & 4.62 \\
31 & 19 & 32 & 2.32 & 71 & 1 & 39 & 0 \\
32 & 20 & 21 & 1.66 & 72 & 2 & 40 & 0 \\
33 & 20 & 33 & 2.52 & 73 & 3 & 41 & 0 \\
34 & 21 & 22 & 1.50 & 74 & 4 & 42 & 0 \\
35 & 21 & 34 & 2.66 & 75 & 5 & 43 & 0 \\
36 & 21 & 36 & 2.72 & 76 & 6 & 44 & 0 \\
37 & 22 & 37 & 2.82 & 77 & 8 & 45 & 0 \\
38 & 23 & 24 & 3.34 & 78 & 10 & 46 & 0 \\
39 & 23 & 38 & 2.86 & 79 & 12 & 47 & 0 \\
40 & 24 & 25 & 2.30 & & & & \\
\hline & & & & & & &
\end{tabular}

ただし，T：リンクの所要時間

$T_{0}$ : 交通量が 0 のときのリンクの所要時閒

$R:$ 容最に対する交通量の比

シミュレーションにおいてゾーン間交通量の一定制命 在配分していく増分交通最はゾーン間の総パーソントリ ップの $5 \%$ とする。乗用本の闬乘率は 1 人/台, バスの 蚐乗串人数は 20 人/台とする。

混雑度限界の式は $1.5+0.5$ cを朋いることにし，c= 1 から壮発して/復汒算ごとに0.5 分 $/ \mathrm{km}$ ずつ混雑度限

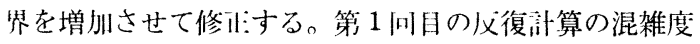
限界は 2.0 分 $/ \mathrm{km}$ である。

TRADIT の初期のリンク速度は $40 \mathrm{~km} /$ 時 とし, 機 関別分担を行ならときの道路網のリンクの所要時間と配 分結果のリンクの所要時間との差がすべて $5 \%$ 以内にお さまるまでフィードバックを行なうことにする。もし収 束しない場合, フィードバックは最大 10 回とする。
これらの条件に基づいて INCREM と TRADIT の シミュレーションを行ない, 雨モデルの結果の比較を行 なう。

\section{（2）シミュレーションの結果の検討}

これらのモデルを評価する場今，与えられた()D表が 们じであ，ても配分千法によ，て個々のリンクの配分結 果も晎な一てくるし ${ }^{8)}$ ，段階的増加交通配分法に打いて ゾーンペアの選び方（ランダムに選ぼうとも）によって 得られる結果が異なるので，一番基淮となるものは，ジ ーンペアの機関別分担が正確に行なわれているかどうか である。従来の手法である TRADIT の結果自体も必ず しも真の值に近いとは言えないが，現在の交通計画で一 般に用いられているので, 比較の都合上TRADITを基 準にとって INCREM のゾーンペアの機関別分担と比ベ ることにした。

そこで, まず最初に 乗用車と大量輸送機関 の総トリップ数を比較 すると表一3のように

\section{表-3 交通機関別分担量}

\begin{tabular}{c|c|c}
\hline Model & Car & Transit \\
\hline INCREM & 208621 & 221789 \\
TRADIT & 210474 & 219936 \\
\hline
\end{tabular}
なる。ただし，TRADIT はフィードバックを 10 回行 なっても収束しなかったので，10 回目のフィードバッ クの結果を示してある。TRADIT を基隻とした場へ, INCREM との機関別トリップ数の差は非常にわずかで あり，两モデルの結果にはほとんど差はない。

次に, ゾーンペアごとの分担率を示すと表一4のよう になる。TRADIT は 10 回目のフィードバックの結果 を示している。両モデルの最大の差は $15 \%$ で, それも 3 ゾーンペアを数えるだけで, その他のゾーンペアはす ベて $10 \%$ 以内の差である。このように, 交通機関別の 分担率の比較において, 両モデルの間には大きな差はな く, INCREM の妥当性が一応評価されたと思われる。 なお 78 ゾーンペアの大量輸送機関の分担率のうち, 47 ゾーンペアでは INCREM の方が大きな值, 22 ゾ ーンペアでは同一，9ゾーンペアでは少ない值となって おり, 全般にINCREM の方が大量輸送機関の分担率が 大きくなっている。これは第 4 節の 2 番目の問題点のと ころで述べたように, 乗用本の配分済交通量をその需要 量よりも増分交通量，才なわち全目的 PTOD 表の 5\% 以内の差で少なくしたためと考えられる。その結果, INCREM では TRADIT に比べて乗用車の分担率が少 なくなって, 大量輸送機関の分担率 が大きくなってい る。したがって, 需要量と配分済交通量の均衡点のずれ の問題については, 結果的には大きな影響をおよぼさな かったことがわかる。その理由としては, 配分プロセス において混雑度限界を設け, 混雑度限界ごとに反復計算 をくり返し，その限界に達したゾーンペアは一時配分計 
表 4 大量輸送機関の分担率

INCREM

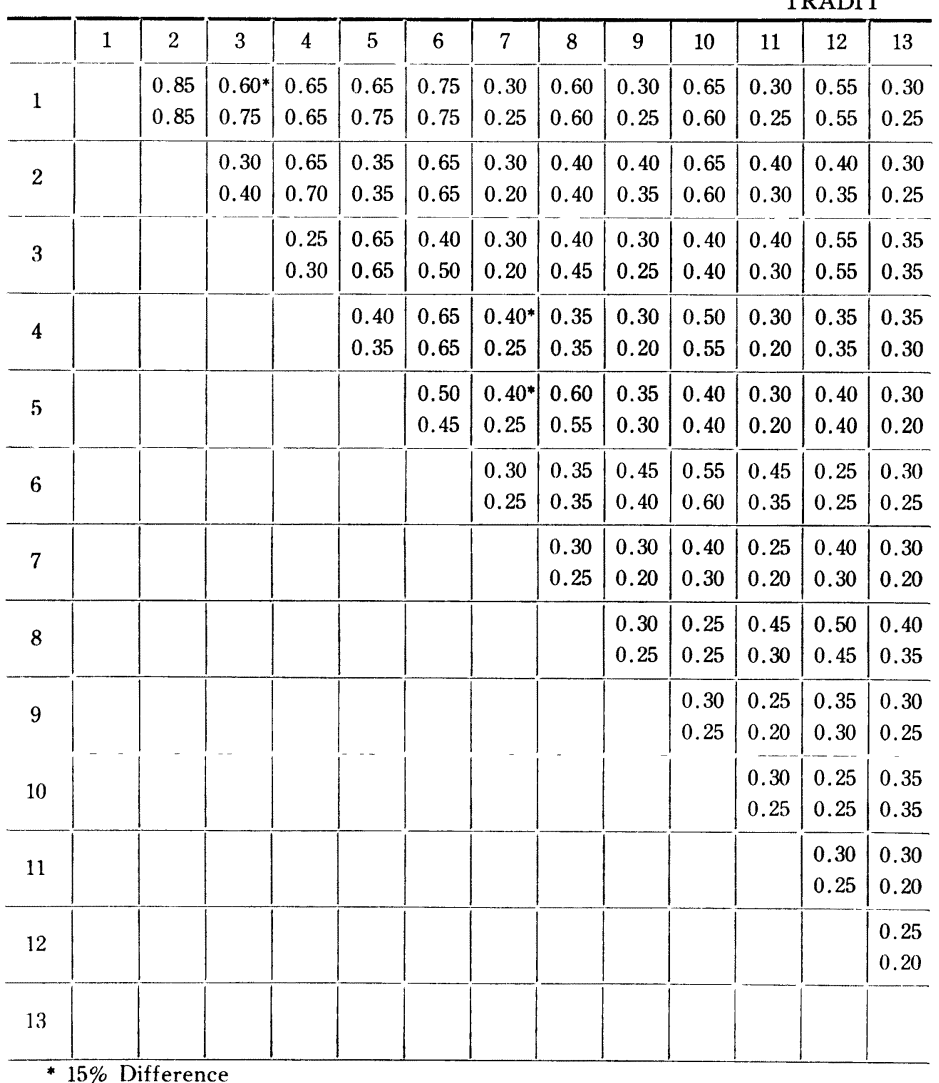

閒比に達するまで最初に求めた最短経路 に人カゾーン間交通量，すなわち 7212 トリップの $5 \%$ ずつを道路網に配分して いく。時間比が $c=1$ に達すると大量輸 送機関の需要量, この例では入力ゾーン 間交通量の 43\%，すなわち3100トリッ プを鉄道網に配分する。次に,ゾーン間 の最短経路を修正して, 乗用車のトリッ プを時間比が $c=2$ になるまで配分する。 このゾーンペアでは, 混雑度限界が $c=$ 2 に達する前に均衡解が得られた。大量 輸送機関の方はそのときの需要量 $55 \%$ から $c=1$ のときの需要量を差引いた残 り $12 \%$ をすべてのゾーンペアの混雑度 限界が $c=2$ に達したとき鉄道網に配分 する。

これまで乱数の発生順序の違いによる シミュレーションの結果への影響につい て言及しなかったが，最後に INCREM の乱数発生の順番を変えてシミュレーシ ヨンを行ない，この問題について検討し てみることにする。そこで, 両者のゾー ンペアの分担摔を比較すると，すべて 5 \% 以内の差におさまり, 78 ゾーンペア のらち 20 ペアが $5 \%$ の差で，その他の ゾーンペアはすべて同じ分担率であ一

算を中止したので それが結果的に各 ゾーンペアがばら ばらに均衡点に達 するのを防ぐ役目 を果たしたためと 考えられる。

次に INCREM の任意のゾーンペ ア(1)一(12)を選んで 利用率曲線と配分 洺曲線の関係を示

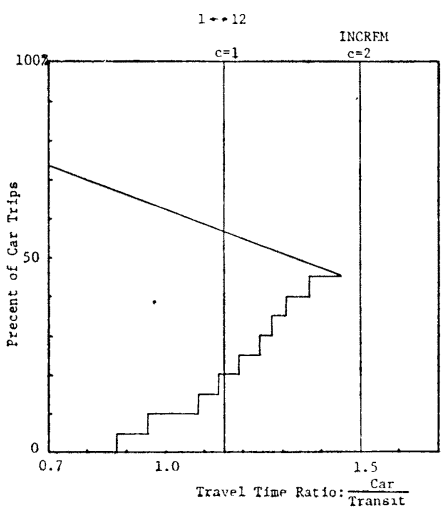

図-14 利用率曲線と配分率曲線の一例 すと図一14 のようになる。このゾーンペアの乗用車の 競合交通手段は 鉄道であり，乗用車の分担率は $45 \%$, 大量輸送機関の分担率は $55 \%$ になっている。ゾーン間 (1)一(12)では目的 A, B のトリップがそれぞれ 5 456, 1756 トリップなので，図一13 の目的別利用率曲線をこれら のトリップで重みづけを行ならと図一14 の利用率曲線 が求まる。

この例では, $c=1$ の混雑度限界が 2.0 分 $/ \mathrm{km}$ である ため, そのときの時間比は 1.145 となっている。この時
た。その結果，乱数発生の違いによる機関別分担への影 響はあまり大きくないことがわかる。

以上のシミュレーションには東京大学大型計算機セン ターの HITAC $5020 \mathrm{E}$ を用いた。INCREM の全計 算時間は 210 秒でそのうち純粋な計算時間は 27 秒であ った。同じくTRADIT の全計算時間は 1154 秒でそ のうち 207 秒が純粋な計算時間であった。これらのモデ ルは段階的増加交通配分法を基本にしているため，シミ ュレーションの過程においてゾーン間の最短経路を記憶 しておく必要があり，その経路の記憶には非常に多くの 記憶容量を必要とするのでコアではなく，外部䛉憶装置 のドラムを用いた。ゾーンペアをランダムに選ぶたびに 最短経路をドラムから取出し, その出人れに時間を要し たため, 全計算時間が純粋な汸算時間上りかなり垴くな っている。

TRADIT に比べて INCREM の訃算時間がはるかに 短くなっているのは, INCREM は結局シミュレーショ ンの反復計算の過程に TRADIT のフィードバックを組 入れたモデルであり，TRADIT のようにフィードバッ クを必要としないためである。

従来のような予測方式では，ほとんど TRADIT のよ 
らなフィードバックを行なわないのが普通であり，これ では第 2 節で説明したように, 道路の混雑度に関係なく ゾーン間交通量が一定となる矛盾を有している。この問 題を解決するために, フィードバックといら概念が一般 に取入れられているが，このフィードバックが収束する 保証は全然なく，かつ非常に長時間の計算を必要する。 ところが, INCREM は交通機関別の分担率の比較にお いて, TRADIT の結果とそれほど大きな差はなく, 計 算時間がはるかに短くて済み, 害用的である。さらに, 段階的增加交通配分法を基礎としているため, 従来の配, 分手法に比べて論理的に優れているといえる。

\section{7. まとめと今後の発展}

本論文は増加交通配分法の特色を生かし, 機関別分担 を配分交通に組み入れた配分手法に発展させた。これに よって, ジーン間の交通機関別の需要量を一定として固 定する必要はなく, ゾーン間のサービス指標を変数とし て表わされることができ, 発生率曲線のアイデアを一歩 前進させることができた。

この新しい配分手法の妥当性を検討するために, 簡単 な仮想都市を想定し, 従来の機関別分担と配分交通を分 離して子測する方法と比較した。その結果, 簡単な事例 ではあるが，陠モデルの結果には大きな差はなく，计算 時間が従来の方法に比べてはるかに短く, この新しい手 法の有效州が一応評価できた。

しかし, 発生率曲線のかわりに用いた利用率曲線は, もともとジーン間の総パーソントリップを一定として機 関別の分担率を決める曲線であるため, この配分手法に おいてもゾーン間の総パーソントリップは一定であると いら前提を設けざるを得なかった。その結果, 乗用車の 競合交通手段がバスのみで両交通機関が同ルートの場 合, 時間比を変数にした利用率曲線を用いると, 両交通 機関の速度 (時間) 比は一定となり, 機関別の需要量が 一-定になってしまう問題点が生じた。本来パーソントリ ップも一定でなく, ゾーン閒の所要時間等のサービス指 標を変数として表わされるはずである。そのためには, 従来の子測プロ七スの発生交通, 分布交通, 機関別分担
を一つにまとめた需要モデルが必要になる。

この需要モデルはジーン間のサービス指標, 各ゾーン の土地利用のアクティビィティ特性を変数として機関別 の需要の絶対量を表わした曲線になり, これが本来の発 生率曲線である。このような需要モデルは都市間の需要 量を予測するモデルとして, Baumol や Quandt 等に よっていくつか提案されているが9)，都市内の-予測モデ ルとしてはまだ実用的なものは提案されていない。

しかし，このようなモデルが実用化されると, 増加交 通配分法は従来の発生交通から配分交通までの 4 段階方 式の需要予測プロセスを一つにまとめたものになり，モ デルとして完成することになる。なお, 配分交通に機関 別分担を組入れる基本的な考え方は，広島都市高速鉄道 嗃画の需要予測で実際に採用していただいた ${ }^{10) 。 ~}$

最後に, この論文の研究に際し東京大学都市工学科 井上孝教授, 新谷洋二助教授のご指導を受け, さらに同 学科 山川仁助手, 建設省建築研究所 黒川洸研究員に 貴重な助言をいただいたことを感謝いたします。

\section{参考 文 献}

1) Martin, B.V. and Manheim, M.L. : A Research Program for Comparison of Traffic Assignment Techniques, HRB Record No. 88, pp. 69-84, 1965.

2) Martin, B.V. : A Computer Program for Traffic Assignment Research, MIT Report, 1964.

3）井上 孝・杉恵頼寧: 発生率曲線に上る增加交通配分法, 第 23 回土朴学会学術講演会 $\mathrm{N}$, pp. $425-426,1968$.

4）杉恵頼寧: 增加交通配分法の研究, 渞路, pp. 40-47, 1971. 1.

5）広島都市交通問題㮣談会: 広島都市圈に打ける 総合的交 通計画, 都市計画 63 号, pp. 2-34, 1970. 7 .

6）広島都市交通研究会：交通機関別分担の実態とその計量, Technical Report No. 6, 1971. 7.

7）広島都市交通研究会: 交通量の路線配分の検討, Technical Report No. 2, 1970. 4.

8）井上 孝・杉恵頼寧：都市道路網の配分交通比関する基 礎的研究, 日本都市計画学会第 3 回 学術講演会論文集, pp. 25-34, 1968.

9) Quandt, R.E. and Baumol, W.L. : The Demand for Abstract Transport Method: Theory and Measurement, Journal of Regional Science, Vol. 6, No. 2, Winter, pp. 13-26, 1966.

10）広島都市交通研究会: 広島都市高速鉄道計画 No. 1 , pp. 13-35, 1971.

(1971.6.14 - 受 付 